\title{
EFL STUDENTS' PREFERENCES TOWARDS WRITTEN CORRECTIVE FEEDBACK: AN EXPLORATORY STUDY ON AGE AND LEVEL OF PROFICIENCY ${ }^{1}$
}

\author{
Sara Orts \\ Patricia Salazar
}

Universitat Jaume I

\begin{abstract}
Corrective feedback ( $\mathrm{CF}$, henceforth) has been an issue of investigation in second language acquisition for a number of years now. In the English-as-aforeign-language classroom, students may have different preferences towards how to have their errors corrected. Research has shown that differences in the learning styles of the students will affect the learning environment by either supporting or inhibiting their intentional cognition and active engagement. In the classroom, teachers can use this information as a tool to motivate students and help them improve their learning process. This exploratory study was carried out to analyse students' preferences towards written correction in two different groups at a high school in Spain. Students filled out a questionnaire and results were analysed in order to determine whether age and level of English may be factors affecting their preferences for error correction.
\end{abstract}

Keywords: corrective feedback, age, proficiency, preferences, error.

\section{Resumen}

La retroalimentación correctiva lleva años siendo un tema de investigación en el campo de la adquisición de segundas lenguas. En el aula de inglés como lengua extranjera, los estudiantes pueden mostrar preferencias distintas en lo que respecta a la corrección de sus errores. Investigaciones anteriores revelan que las diferencias en los estilos de aprendizaje de los estudiantes pueden afectar el clima de aprendizaje, bien reforzando o inhibiendo su participación. De esta forma, en el aula, los profesores pueden utilizar esta información como herramienta para motivar a los estudiantes y ayudarles a mejorar en el proceso de aprendizaje. El presente estudio exploratorio tiene como objetivo analizar las preferencias de dos grupos de estudiantes españoles hacia la corrección escrita. Los participantes rellenaron un cuestionario para determinar si la edad y nivel de competencia en inglés pueden ser factores que afecten sus preferencias hacia la corrección de errores.

Palabras clave: retroalimentación correctiva, edad, nivel de competencia, preferencias, error.

\footnotetext{
${ }^{1}$ This study was conducted within the framework of a research project funded by Universitat Jaume I (P1.1B2015-20).
} 


\section{Introduction}

About thirty years ago, Touchie stated that "language learning, like any kind of human learning, involves committing errors" $(1986,75)$. The treatment of these errors in the English-as-a-foreign language (EFL, henceforth) classroom has been a matter of concern for some years. Its importance emerged with the rise of learner-centred approaches to writing instruction in L1 composition classes in the 1970s (Hyland and Hyland 2006). Ferris admits that "it is unrealistic to expect that L2 writers' production will be error free" $(2002,5)$ and she claims that errors in the second language classroom should be treated. In the late 70s, Hendrickson (1978) set forth that learners were not always able to identify their own mistakes and thus they needed a more expert source to help them find those mistakes. About thirty years later, Zacharias (2007) explained that most students firmly took for granted that teacher feedback was a keystone to improve their writings as they assumed teachers were more competent in terms of linguistic knowledge. ${ }^{2}$

Authors like Dulay and Burt (1974) regarded error making as inevitable and necessary to language learning. It is even considered a symptom to show that the learner is in the developmental process of learning and internalising the rules of the target language. As Alavi and Kaivanpanah put it "providing language learners with clear feedback plays a crucial role in developing learners' language abilities and helping them direct their learning" (2007, 181). Similarly, Zacharias (2007) enhances the importance of written feedback by suggesting that providing feedback can be a way to help students improve the quality of their writing and increase their motivation in such practice. However, Touchie (1986) considers that teachers should not correct all students' errors since it could be disruptive in their learning process and discourage them from communicating. He agrees on correcting errors which interfere with the understanding of the message and affect communication. Additionally, this author maintained that errors occurring frequently and affecting a large number of students must be corrected over less frequent errors and those affecting few students in the classroom.

Contrary to many researchers on SLA, Truscott (1996) defined corrective feedback as ineffective and harmful for learners. This author pointed out students' unwillingness to change their intuitions and adopt their teacher's correction. He claimed that they either continued writing as they had done before or avoided the conflictive word or structure in following writings, adopting a negative or passive attitude towards teachers' corrections. By the same token, Lee claimed that "to date there is no research evidence to show that more error feedback would lead to better or faster development of grammatical accuracy in writing" $(2003,156)$. Nevertheless, the great majority of research on error

\footnotetext{
${ }^{2}$ Corder (1973) was the first author to distinguish between error and mistake in interlanguage, and classified errors in terms of the difference between the learners' utterance and the reconstructed version. He proposed a non-exhaustive classification of errors: omission of some required element, addition of some unnecessary or incorrect element, selection of an incorrect element, and misordering of the elements. In the present paper, we will be using the term 'error' and 'mistake' interchangeably.
} 
correction suggests that it should take place in SLA classrooms. Moreover, studies measuring students' improvement from a longitudinal approach prove that students receiving feedback on errors over a period of time can improve their language accuracy (Fathman and Whalley 1990; Ferris and Helt 2000; Ferris and Roberts 2001; Ferris 2002).

\section{Theoretical background}

\section{1. Students' preferences towards corrective feedback}

According to Hyland and Hyland, "ESL students, particularly those from cultures where teachers are highly directive, generally welcome and expect teachers to notice and comment on their errors and may feel resentful if their teacher does not do so" $(2006,3)$. Preferences may be affected by students' context, which they define as a frame which encloses feedback and offers resources for its proper interpretation. The institution itself, the classroom's principles, students' goals in learning to write, their abilities, and the genres studied are frequently important but ignored variables in studies on feedback.

Research on EFL students' preferences to teacher feedback demonstrate that learners keep in mind and appreciate encouraging comments and expect constructive criticism instead of clichéd remarks (Ferris 1995a; Hyland 1998). Some authors maintain that corrections are not as discouraging to ESL and EFL students as for native speakers of the language, since they do not invest so much self-esteem in their writings as native speakers do (Leki 1991; Schachter 1991).

A number of studies investigating students' preferences to teacher feedback (Cohen and Cavalcanti 1990; Leki 1991; Hedgcock and Lefkowitz 1994, 1996; Ferris 1995b) showed that learners consider teacher feedback valuable and helpful in order to improve their writing. As Ferris (2003) claims, if students do not get what they believe they need, they may lose motivation. Furthermore, results point to a students' preference for specific comments and suggestions for revising, together with the fact that learners tend to prefer direct feedback rather than indirect correction (Ferris and Roberts 2001; Chandler 2003). For example, Lim (1990) investigated the attitudes, opinions and expectations of Singapore secondary school students to error and feedback and found out a positive attitude toward peer correction in the classroom. Students preferred their grammar errors to be corrected first, followed by vocabulary, spelling, organization of ideas, and punctuation errors. Her findings showed that students wanted to take an active part in correcting the error, but they stated that the primary responsibility for correcting errors lay on the teacher.

Leki's (1991) findings showed that ESL students valued grammar as the most important aspect in writing, followed by spelling, vocabulary and punctuation. However, she reported that not all of them always looked carefully at the corrections in those areas. Moreover, none of the students in the study wanted to receive indirect correction, indeed, the students wanted direct correction along with metalinguistic clues to assist them in correcting the error. 
In turn, Oladejo (1993) analysed whether students' preferences differed according to their level of proficiency in the target language. His findings revealed that learners did not favour peer correction and it was not successful for advanced learners, although this correction technique may be successful for intermediate ones. The majority of students in the study showed a preference for organization of ideas to be corrected, followed by grammar errors, vocabulary errors and finally spelling and punctuation errors.

Hedgcock and Lefkowitz (1994) conducted a survey study of 110 ESL and 137 EFL (French, German and Spanish) students and found that both groups had a positive attitude toward written corrective feedback. However, they reported that EFL students had a preference for correction on grammar, vocabulary, content and style, while ESL students preferred feedback on content and organization. In this line of research, Sheen (2011) pointed out that this EFL students' preference for feedback on linguistic features matches the students' priorities and goals in learning, as EFL learners are more interested in developing their L2 knowledge, while ESL learners focus on developing their writing skill. Sheen concludes that "the learning context may determine how learners respond to the corrective feedback they receive" $(2011,44)$. Besides, individual factors such as proficiency level, learning style, personality of the subject and motivation may have an impact in the way learners respond to corrective feedback.

In the study conducted by Storch and Wigglesworth (2010), findings showed that the effectiveness of written corrective feedback depended on the type of errors made and the learners' level of proficiency. They suggested that particular elements like learners' attitudes, beliefs and objectives are essential factors, though usually neglected in written corrective feedback research, in determining if learners were able to benefit from feedback.

Although similar opinions on the topic would be desirable, teachers and students often have different attitudes on error correction. As Oladejo puts it 'teachers' opinion and classroom practice regarding corrective feedback do not always match the perceived needs and expectations of learners; such as correcting all errors as they appear, while others believe that constant correction can boost students' level of anxiety and thus hinder learning" (1993, 84). Similarly to teachers, some students prefer being corrected more than others but there is a tendency for all students wishing to be corrected, as Leki's (1991) study mentioned above corroborated. Apart from this study, many others have shown that L2 learners want teacher correction in the classroom (Ferris, 1995b; Hedgcock \& Lefkowitz, 1994, 1996). However, some students find constant correction deterring and irritating. They can even become frustrated and refuse to participate in order to prevent committing errors (Zhu, 2010). Due to these different attitudes, Zhu maintains that "both teachers and students should adopt a reasonable approach to handle the error-correction problem effectively and appropriately in order to adapt to their preferences in learning and teaching" (2010, 128). Schulz (1996) also states that by knowing students' attitudes 
towards error correction teachers can adapt to the learner's needs and preferences, a fact which may influence the effectiveness of teachers' feedback.

According to Sheen (2011), one of the reasons why corrective feedback has shown manifold results in research regarding the efficacy of teachers' correction is learner variables. Sheen explains that "individual difference (ID) variablessuch as language aptitude, anxiety, and attitudes towards corrective feedbackinfluence learners' receptivity to error correction and thus the effectiveness of the feedback" $(2011,129)$. She adds that learners differ according to both cognitive factors, such as language proficiency, intelligence and learning strategies, and affective factors (for example, level of anxiety, attitudes and degree of motivation). These variables may affect the process of language learning and its subsequent outcomes. For example, a study conducted by Havranek and Cesnik (2001) showed that corrective feedback benefited learners with a positive attitude towards error correction and with a high language level. Schulz's (1996) findings indicated that the participants in her study (ESL learners) had positive attitudes towards error correction. Schulz (2001) conducted a follow-up study with FL students and reported that those learners also considered explicit grammar instruction and corrective feedback essential in language learning. We can conclude from this study that learners with a preference for grammatical accuracy have a positive attitude towards error correction. This fact may also impact on corrective feedback and grammatical accuracy, as those learners with positive attitudes may benefit more from corrective feedback than those with negative ones (Sheen, 2011).

\subsection{Students' preferences and level of proficiency}

Learners' variables, as mentioned above, seem to influence the effectiveness of corrective feedback. Some early research on oral correction (Ammar and Spada, 2006; Havranek and Cesnik, 2001) has shown that higher proficient students benefited more from $\mathrm{CF}$-that is, they obtained higher scores in the post-test- than students with lower proficiency levels. This is particularly relevant in the case of recasts (Lyster and Ranta, 1997), since they may foster language development for high-proficiency learners. In their study, Ammar and Spada (2006) found that only students with a high proficiency level were helped by recasts, whereas both low- and high-proficiency students benefited from prompts.

In a very recent study on students' perceptions and preferences of corrective feedback, Chen et al. (2016) claim that, irrespective of level (intermediate, advanced-intermediate, and advanced), their EFL participants reported a preference towards error correction, especially on content and organization, and were more favourable to direct rather than indirect feedback, in line with Amrhein and Nassaji's (2010) results from ESL learners. Chen et al. (2016) also state that students at all levels expect teacher's comments on grammar, whereas advanced learners would like more feedback on content and structure of their writings. 


\subsection{Students' preferences and age}

Age is the second factor we are taking into account to examine its likely impact on students' preferences towards CF. As Zarei (2011) points out, CF has to be compatible with students' needs and preferences in order for correction to be effective. These needs may differ from one age group to another. In her study, Zarei (2011) used a questionnaire on treatment of errors and error correction with two age groups (15-20 and 20-35 year-old Iranian students). Overall findings show that older students want to have all their errors corrected, irrespective of their frequency. Moreover, the percentages for explicit correction and metalinguistic feedback were statistically significant for the older group. According to the author, these results may be attributed to the fact that adult learners benefit more from explicit instruction due to their cognitive development. Moreover, in the specific case of the Iranian context, older students are accustomed to a teacher-centred approach.

Taking into account the literature discussed above, the aim of this exploratory study is to contribute to the body of research examining what factors may influence EFL students' preferences for error correction and feedback. Specifically, we seek to analyse whether the variables of age and level of proficiency have an impact on students' preferences and opinions about CF. In order to do so, the following research question has been formulated:

RQ: What are students' preferences for error correction and feedback taking into account the variables of age and level?

\section{The study}

\subsection{Participants}

Two groups of students $(n=53)$ belonging to two different intact classes participated in the study. The first group was composed of 29 students in 4th year of Spanish Compulsory Education (ESO), 18 male and 11 female students. The students' ages ranged from 15 to 16 years old. The second group was composed of 24 students in the 2nd year of Bachillerato. There were 17 female and 7 male students between 17 and 18 years old.

The Quick Placement Test (Oxford, 2001) was administered to students in order to determine their level of proficiency. Table 1 illustrates the level of proficiency of participants in both groups according to the Common European Framework of Reference for Languages (CEFR). 
Table 1. Level of proficiency of subjects in the study

\begin{tabular}{|l|c|c|c|c|c|c|}
\hline \multicolumn{4}{|c|}{ GROUP 1 (n=29) } & \multicolumn{3}{|c|}{ GROUP 2 (n=24) } \\
\hline $\begin{array}{l}\text { Level of } \\
\text { proficiency }\end{array}$ & A2 & B1 & B2 & A2 & B1 & B2 \\
\hline $\begin{array}{l}\text { Number of } \\
\text { students }\end{array}$ & 13 & 12 & 4 & 6 & 12 & 6 \\
\hline
\end{tabular}

The vast majority of participants $(92 \%)$ were Spanish, but two other nationalities (Romanian, $6 \%$ and Ecuadorian, $2 \%$ ) were also present in the study. As for the mother tongue of participants, $61 \%$ of Spanish students stated it was Catalan, 26\% Spanish and 13\% could speak both. These percentages are due to the existence of two co-official languages in the context of the present study. Romanian students claimed Romanian was their mother tongue.

\subsection{Data collection procedure}

Data were collected by means of a 12-item questionnaire which was filled out by the two EFL groups. This questionnaire, adapted from Hamouda (2011, see appendix 1) asked about students' preferences towards written corrective feedback. The questionnaire was translated into Catalan so that participants could fully understand the different questions.

\subsection{Results and discussion}

As can be seen in Table 2 below, which examines the first variable (that is, students' age), the majority of students prefer being corrected with a red pen (92\% in Group 1 and 88\% in Group 2, respectively). Also, both groups want the teacher to be the one who corrects (89\% and 92\%), keeping self-correction with percentages below 10\%. In turn, responses for item 3 show that all students in Group 2 prefer to have all their errors corrected and $4 \%$ of students in the youngest group (Group 1) would rather be corrected only some of the errors they had made. This result concurs with Zarei's (2011) findings which reveal that the older group of students want to have their errors corrected at all times.

Results for item 4 show a higher preference for getting the right answer instead of letting the students themselves correct their errors, although the percentages are quite balanced in both groups irrespective of age. Unlike previous studies which show a preference for explicit feedback for older learners (Zarei, 2011), our participants prefer the teacher to cross out the errors and to give the appropriate word (65\% in Group 1 and $50 \%$ of the answers in Group 2). Still, a high percentage of students prefer the teacher to underline the errors and to write comments at the end of the essay, as attested in item 6. Only a low percentage (4\% in Group 1 and $8 \%$ in Group 2) chose a correction code as a technique to have their errors corrected. 
Most students from both groups like receiving specific and detailed comments from the teacher when given an essay back. Students in Group 1 considered grammar, content, organization and vocabulary as equally important factors in an essay. Students in Group 2 favoured grammar and content $(50 \%$ each), but none of them chose either organization or vocabulary, in line with previous research (Lim 1990; Leki 1991). As for item 8, both groups claimed the teacher should point out grammar errors (73\% in Group 1 and $75 \%$ in Group 2) over vocabulary and other types of errors. The answers for item 9 reveal that the vast majority of students in both groups want correction even if understanding of the message is not hindered (93\% in Group 1 and 96\% in Group 2), in line with previous research on the topic (Lyster et al., 2013).

Similar percentages are obtained for item 10: irrespective of age, both groups report the desire to have all their errors corrected, a finding which differs from Zarei's (2011) study as she found that younger students had lower scores for frequent errors when compared to older students $(40.3 \%$ vs. $68.4 \%$, respectively).

Seventy-three per cent of students in Group 1 considered they would not repeat a corrected error in the future (item 11); however, answers are equally balanced in Group 2, as 50\% reported they would make the same mistake in subsequent writings. Finally, item 12 shows that age does not seem to be a discriminating factor, since participants stated that both the teacher and the students should get involved in the task of spotting and correcting mistakes. Only a higher percentage is found in Group 2 which claimed that this task should be the teacher's ( $58 \%$ vs. $42 \%$ ), as Ferris (1995b) had also reported.

Table 2. Students' preferences per age

\begin{tabular}{|c|c|c|c|c|}
\hline & \multicolumn{4}{|c|}{ Group 1 / Group 2} \\
\hline $\begin{array}{l}\text { 1. I prefer my } \\
\text { teacher to } \\
\text { correct my } \\
\text { essays in... }\end{array}$ & $\begin{array}{l}\text { Red pen } \\
\mathbf{9 2 \% ~ / ~} \\
\mathbf{8 8 \%}\end{array}$ & $\begin{array}{l}\text { Green pen } \\
\mathbf{4 \% / 1 2 \%}\end{array}$ & $\begin{array}{c}\text { Pencil } \\
4 \% / 0 \%\end{array}$ & - \\
\hline $\begin{array}{ll}2 . & \text { Who do } \\
\text { you prefer } \\
\text { to correct } \\
\text { your } \\
\text { essays? }\end{array}$ & $\begin{array}{c}\text { The teacher } \\
\text { 89\% / } \\
\mathbf{9 2 \%}\end{array}$ & $\begin{array}{c}\text { My } \\
\text { classmates } \\
\mathbf{4 \% / 0 \%}\end{array}$ & $\begin{array}{c}\text { Self- } \\
\text { correction } \\
\mathbf{7 \%} / \mathbf{8 \%}\end{array}$ & - \\
\hline $\begin{array}{ll}\text { 3. } & \text { In my } \\
\text { essays, I } \\
\text { prefer the } \\
\text { teacher to }\end{array}$ & $\begin{array}{l}\text { All the } \\
\text { errors } \\
\mathbf{9 6 \%} \text { / } \\
\mathbf{1 0 0 \%}\end{array}$ & $\begin{array}{l}\text { Some } \\
\text { errors } \\
4 \% / 0 \%\end{array}$ & - & - \\
\hline
\end{tabular}




\begin{tabular}{|c|c|c|c|c|c|}
\hline \multicolumn{2}{|r|}{ highlight... } & & & & \\
\hline & $\begin{array}{l}\text { I prefer the } \\
\text { teacher... }\end{array}$ & $\begin{array}{l}\text { Tells me } \\
\text { the right } \\
\text { answer } \\
\mathbf{5 5 \% ~ / ~} \\
\mathbf{6 3 \%}\end{array}$ & $\begin{array}{l}\text { Marks the } \\
\text { errors and I } \\
\text { correct } \\
\text { them } \\
\mathbf{4 5 \% / 3 7 \%}\end{array}$ & - & - \\
\hline & $\begin{array}{l}\text { What do } \\
\text { you prefer } \\
\text { the teacher } \\
\text { does to } \\
\text { correct } \\
\text { your } \\
\text { essays? }\end{array}$ & $\begin{array}{c}\text { Cross the } \\
\text { errors out } \\
\text { and give } \\
\text { the } \\
\text { appropriate } \\
\text { words } \\
\mathbf{6 5 \%} \text { / } \\
\mathbf{5 0 \%}\end{array}$ & $\begin{array}{l}\text { Underline } \\
\text { the errors } \\
\text { and write } \\
\text { comments } \\
\text { at the end } \\
\text { of the essay } \\
\mathbf{3 1 \% / 4 2 \%}\end{array}$ & 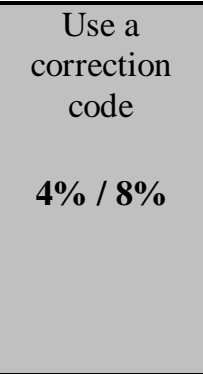 & $\begin{array}{c}\text { Write } \\
\text { questions } \\
\mathbf{0 \% / 0 \%}\end{array}$ \\
\hline & $\begin{array}{l}\text { What kind } \\
\text { of } \\
\text { comments } \\
\text { would you } \\
\text { like your } \\
\text { teacher to } \\
\text { make when } \\
\text { giving an } \\
\text { essay } \\
\text { back? }\end{array}$ & $\begin{array}{c}\text { General } \\
\text { comments } \\
\\
\mathbf{2 4 \%} \text { / } \\
\mathbf{1 7 \%}\end{array}$ & $\begin{array}{c}\text { Specific } \\
\text { and } \\
\text { detailed } \\
\text { comments }\end{array}$ & $\begin{array}{l}\text { Positive } \\
\text { comments } \\
\mathbf{4 \% / 8 \%}\end{array}$ & $\begin{array}{l}\text { Negative } \\
\text { comments } \\
\mathbf{4 \% / 4 \%}\end{array}$ \\
\hline 7. & $\begin{array}{l}\text { The most } \\
\text { important } \\
\text { in an essay } \\
\text { is... }\end{array}$ & $\begin{array}{l}\text { Grammar } \\
\text { 31\% / } \\
50 \%\end{array}$ & $\begin{array}{c}\text { Content } \\
\mathbf{2 4 \% / 5 0 \%}\end{array}$ & $\begin{array}{l}\text { Organization } \\
\mathbf{2 4 \% / 0 \%}\end{array}$ & $\begin{array}{l}\text { Vocabulary } \\
21 \% / 0 \%\end{array}$ \\
\hline 8 . & $\begin{array}{l}\text { In your } \\
\text { essays, the } \\
\text { teacher } \\
\text { should } \\
\text { point out... }\end{array}$ & $\begin{array}{l}\text { Grammar } \\
\text { errors } \\
\\
\mathbf{7 3 \%} \text { / } \\
\mathbf{7 5 \%}\end{array}$ & $\begin{array}{l}\begin{array}{c}\text { Vocabulary } \\
\text { errors }\end{array} \\
\mathbf{1 0 \% / 4 \%}\end{array}$ & $\begin{array}{c}\text { Other } \\
\mathbf{1 7 \%} / \mathbf{2 1 \%}\end{array}$ & - \\
\hline 9. & $\begin{array}{l}\text { If an error } \\
\text { does not } \\
\text { affect the } \\
\text { understandi } \\
\text { ng of the }\end{array}$ & $\begin{array}{c}\text { Yes } \\
93 \% \text { / } \\
96 \%\end{array}$ & $\begin{array}{c}\text { No } \\
\mathbf{7 \%} / \mathbf{4 \%}\end{array}$ & - & - \\
\hline
\end{tabular}




\begin{tabular}{|c|c|c|c|c|}
\hline $\begin{array}{l}\text { message, } \\
\text { should it be } \\
\text { corrected? }\end{array}$ & & & & \\
\hline $\begin{array}{l}\text { 10. If there } \\
\text { were many } \\
\text { errors in } \\
\text { your essay, } \\
\text { what would } \\
\text { you like } \\
\text { your } \\
\text { teacher to } \\
\text { do? }\end{array}$ & $\begin{array}{l}\text { Correct all } \\
\text { errors } \\
\\
\mathbf{7 3 \% ~ / ~} \\
\mathbf{6 7 \%}\end{array}$ & $\begin{array}{c}\begin{array}{c}\text { Correct } \\
\text { only }\end{array} \\
\text { serious } \\
\text { errors }\end{array}$ & $\begin{array}{l}\text { Correct errors } \\
\text { affecting } \\
\text { understanding } \\
\mathbf{1 0 \%} / \mathbf{8 \%}\end{array}$ & $\begin{array}{l}\text { Correct all } \\
\text { repeated } \\
\text { errors }\end{array}$ \\
\hline $\begin{array}{l}\text { 11. Once your } \\
\text { errors are } \\
\text { corrected, } \\
\text { do you } \\
\text { think you } \\
\text { will repeat } \\
\text { them? }\end{array}$ & $\begin{array}{c}\text { Yes } \\
\mathbf{2 7 \%} / \\
\mathbf{5 0 \%}\end{array}$ & $\begin{array}{c}\text { No } \\
\mathbf{7 3 \%} / \mathbf{5 0 \%}\end{array}$ & - & - \\
\hline $\begin{array}{l}\text { 12. Which } \\
\text { statement } \\
\text { do you } \\
\text { agree on? }\end{array}$ & $\begin{array}{c}\text { The main } \\
\text { task of the } \\
\text { teacher is } \\
\text { to locate } \\
\text { and correct } \\
\text { students' } \\
\text { errors } \\
\\
\mathbf{4 8 \%} \text { I } \\
\mathbf{5 8 \%}\end{array}$ & $\begin{array}{l}\text { The main } \\
\text { task of } \\
\text { students is } \\
\text { to locate } \\
\text { and correct } \\
\text { their own } \\
\text { errors } \\
\mathbf{5 2 \% / 4 2 \%}\end{array}$ & - & - \\
\hline
\end{tabular}

Statistical analysis was carried out by means of a Chi-square test to the 12 items in the questionnaire using the Statistical Package for the Social Sciences (SSPS) version 20. Only item 7 The most important in an essay is... obtained a statistically significant difference, as Table 3 shows:

Table 3. Significant difference between groups depending on age $(p<0.05)$

\begin{tabular}{|l|c|c|c|}
\hline & Value $\chi^{2}$ & d.f. & Significance \\
\hline $\begin{array}{l}\text { 7. The most important in an essay is... } \\
\text { (grammar/content/organization/vocabulary) }\end{array}$ & 14.401 & 3 & .002 \\
\hline
\end{tabular}


In light of the results, the variable of age does not seem to be a factor as far as students' preferences for correction and feedback are concerned. Only a significant difference was found as for the importance attached to grammar and content in an essay: older students considered them as equally important, without paying attention to organization or vocabulary. The picture is rather different for students in Group 1, since they show similar percentages in all four areas. This was not an expected finding for Group 2, because this group of students are about to take the Spanish university entrance exam (Selectividad) in which they are required to write an essay which is graded taking into account not only grammar and content, but also vocabulary and organization of ideas.

The findings for the second variable in our research question (level of proficiency in English) are displayed in Table 4. Our results are going to be compared to Chen et al.'s (2016) paper for three reasons: first, to our knowledge, it is one of the most recent studies on students' preferences towards CF taking level of proficiency as a variable, second, it also had EFL participants belonging to a context in which form-focused instruction is the main mode of teaching and students have very few opportunities to interact in English outside the classroom. Thirdly, the questionnaire they employed to gather data had many similar items to the one used in the present study so that the responses can be compared.

For item 1, the three groups showed a clear preference for correction in red pen, although more advanced students (B2 level) also chose correction in green pen $(20 \%)$ or pencil $(10 \%)$. Most students in the three groups preferred being corrected by the teacher and having all errors corrected, as results for items 2 and 3 show, in line with Ferris' (1995b) findings. Yet, in Chen et al.'s (2016) study, the Chi-square test showed no statistically significant difference among learners at different levels of proficiency when asked 'it is instructors' responsibility to provide feedback'.

Students with the lowest level of proficiency would rather have the teacher tell them the right answer; in turn, B1 students favoured being given the right answer and correcting the errors themselves equally and $60 \%$ of higher level students preferred to correct the errors themselves. Most A2 and B1 students reported in item 5 that they preferred the teacher to cross out errors and provide the right version, although B2 students would like to have their deviant production underlined and get teacher's comments (60\%). When giving an essay back, most students in the three groups wanted the teacher to give them specific and detailed comments, especially B2 students (90\%). This latter result corroborates Chen et al.'s (2016) findings, as their advanced students preferred comprehensive feedback to simple error correction.

Item 7 reveals that grammar is considered the most important area in an essay by most students, especially by B2 students (70\%). Consequently, the results for item 8 show that grammar errors are labelled as the most important ones the teacher should point out, reaching a $90 \%$ for B2 students. Our percentages do not confirm Chen et al.'s study, as they report consistent 
responses across the three proficiency levels: organizational errors were rated first, followed by grammar and vocabulary errors.

All students with a B1 or B2 level of proficiency reported that errors which do not affect understanding of the message should be corrected as well. In turn, only $16 \%$ of A 2 students consider that this kind of error should not be corrected. Chen et al.'s findings for this item are mixed: same priority is given to errors affecting message comprehensibility and having all errors corrected. As for item 10 , the three groups expressed their preference to have all errors corrected in an essay in which many errors had been made, especially in the case of B2 students (90\%).

Table 4. Students' preferences per level of proficiency

\begin{tabular}{|c|c|c|c|c|}
\hline Level of proficiency & \multicolumn{4}{|c|}{ A2 / B1/ B2 } \\
\hline $\begin{array}{l}\text { 1. I prefer my } \\
\text { teacher to } \\
\text { correct my } \\
\text { essays in... }\end{array}$ & $\begin{array}{c}\text { Red pen } \\
95 \% / 96 \% / 70 \\
\%\end{array}$ & $\begin{array}{c}\text { Green pen } \\
\mathbf{5 \% / 4 \% / 2 0} \\
\%\end{array}$ & $\begin{array}{c}\text { Pencil } \\
\text { 0\%/0\%/10 } \\
\%\end{array}$ & - \\
\hline $\begin{array}{l}\text { 2. Who do you } \\
\text { prefer to } \\
\text { correct your } \\
\text { essays? }\end{array}$ & $\begin{array}{c}\text { The teacher } \\
\text { 95\%/88\%/90 } \\
\%\end{array}$ & $\begin{array}{c}\text { My } \\
\text { classmates } \\
0 \% / 4 \% / 0 \%\end{array}$ & $\begin{array}{c}\text { Self- } \\
\text { correction } \\
\mathbf{5 \% / 8 \% / 1 0} \\
\%\end{array}$ & - \\
\hline $\begin{array}{ll}3 . & \text { In my } \\
\text { essays, I } \\
\text { prefer the } \\
\text { teacher to } \\
\text { highlight... }\end{array}$ & $\begin{array}{c}\text { All the errors } \\
100 \% / 96 \% / 1 \\
00 \%\end{array}$ & $\begin{array}{l}\text { Some errors } \\
0 \% / 4 \% / 0 \%\end{array}$ & - & - \\
\hline $\begin{array}{l}\text { 4. I prefer the } \\
\text { teacher... }\end{array}$ & $\begin{array}{c}\text { Tells me the } \\
\text { right answer } \\
\mathbf{7 9 \% / 5 0 \% / 4 0} \\
\text { \% }\end{array}$ & $\begin{array}{c}\text { Marks the } \\
\text { errors and I } \\
\text { correct them } \\
\text { 21\%/50\%/6 } \\
0 \%\end{array}$ & - & - \\
\hline $\begin{array}{l}\text { 5. What do } \\
\text { you prefer } \\
\text { the teacher } \\
\text { does to } \\
\text { correct your } \\
\text { essays? }\end{array}$ & $\begin{array}{c}\text { Cross the } \\
\text { errors out and } \\
\text { give the } \\
\text { appropriate } \\
\text { words } \\
\mathbf{6 8 \% / 5 8 \% / 4 0}\end{array}$ & $\begin{array}{l}\text { Underline } \\
\text { the errors } \\
\text { and write } \\
\text { comments at } \\
\text { the end of } \\
\text { the essay } \\
\mathbf{3 2 \% / 2 9 \% / 6}\end{array}$ & $\begin{array}{c}\text { Use a } \\
\text { correction } \\
\text { code } \\
\text { 0\%/13\%/0 } \\
\%\end{array}$ & - \\
\hline
\end{tabular}




\begin{tabular}{|c|c|c|c|c|}
\hline & $\%$ & $0 \%$ & & \\
\hline $\begin{array}{l}\text { 6. What kind } \\
\text { of } \\
\text { comments } \\
\text { would you } \\
\text { like your } \\
\text { teacher to } \\
\text { make when } \\
\text { giving an } \\
\text { essay back? }\end{array}$ & $\begin{array}{c}\text { General } \\
\text { comments } \\
\text { 16\%/29\%/10 } \\
\%\end{array}$ & $\begin{array}{l}\text { Specific and } \\
\text { detailed } \\
\text { comments } \\
\text { 79\%/54\%/9 } \\
0 \%\end{array}$ & $\begin{array}{c}\text { Positive } \\
\text { comments } \\
\text { 0\%/13\%/0 } \\
\text { \% }\end{array}$ & $\begin{array}{c}\text { Negative } \\
\text { commen } \\
\text { ts } \\
5 \% / 4 \% / \\
\mathbf{0 \%}\end{array}$ \\
\hline $\begin{array}{l}\text { 7. The most } \\
\text { important in } \\
\text { an essay is... }\end{array}$ & $\begin{array}{c}\text { Grammar } \\
36 \% / 29 \% / 70 \\
\%\end{array}$ & $\begin{array}{c}\text { Content } \\
32 \% / 50 \% / 1 \\
0 \%\end{array}$ & $\begin{array}{l}\text { Organizati } \\
\text { on } \\
16 \% / 17 \% / \\
0 \%\end{array}$ & $\begin{array}{c}\text { Vocabul } \\
\text { ary } \\
16 \% / 4 \\
\% / 20 \%\end{array}$ \\
\hline $\begin{array}{ll}8 . & \text { In your } \\
& \text { essays, the } \\
\text { teacher } \\
\text { should point } \\
\text { out... }\end{array}$ & $\begin{array}{c}\text { Grammar } \\
\text { errors } \\
\text { 74\%/63\%/90 } \\
\%\end{array}$ & $\begin{array}{c}\text { Vocabulary } \\
\text { errors } \\
16 \% / 4 \% / 0 \\
\%\end{array}$ & $\begin{array}{c}\text { Other } \\
10 \% / 33 \% / \\
10 \%\end{array}$ & - \\
\hline $\begin{array}{l}\text { 9. If an error } \\
\text { does not } \\
\text { affect the } \\
\text { understandi } \\
\text { ng of the } \\
\text { message, } \\
\text { should it be } \\
\text { corrected? }\end{array}$ & $\begin{array}{c}\text { Yes } \\
\text { 84\%/100\%/1 } \\
\mathbf{0 0 \%}\end{array}$ & $\begin{array}{c}\text { No } \\
16 \% / 0 \% / 0 \\
\%\end{array}$ & - & - \\
\hline $\begin{array}{l}\text { 10. If there } \\
\text { were many } \\
\text { errors in } \\
\text { your essay, } \\
\text { what would } \\
\text { you like } \\
\text { your teacher } \\
\text { to do? }\end{array}$ & $\begin{array}{c}\text { Correct all } \\
\text { errors } \\
64 \% / 67 \% / 90 \\
\%\end{array}$ & 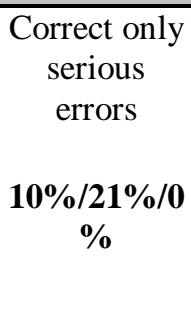 & $\begin{array}{c}\text { Correct } \\
\text { errors } \\
\text { affecting } \\
\text { understand } \\
\quad \text { ing } \\
\\
\mathbf{1 0 \% / 8 \% / 1} \\
\mathbf{0 \%}\end{array}$ & $\begin{array}{l}\text { Correct } \\
\text { all } \\
\text { repeated } \\
\text { errors } \\
\\
16 \% / 4 \\
\% / 0 \%\end{array}$ \\
\hline
\end{tabular}




\begin{tabular}{|c|c|c|c|c|}
\hline $\begin{array}{l}\text { 11. Once your } \\
\text { errors are } \\
\text { corrected, } \\
\text { do you think } \\
\text { you will } \\
\text { repeat } \\
\text { them? }\end{array}$ & $\begin{array}{c}\text { Yes } \\
48 \% / 42 \% / 10 \\
\%\end{array}$ & $\begin{array}{c}\text { No } \\
52 \% / 58 \% / 9 \\
0 \%\end{array}$ & - & - \\
\hline $\begin{array}{l}\text { 12. Which } \\
\text { statement } \\
\text { do you } \\
\text { agree on? }\end{array}$ & $\begin{array}{c}\text { The main task } \\
\text { of the teacher } \\
\text { is to locate } \\
\text { and correct } \\
\text { students' } \\
\text { errors } \\
\text { 63\%/54\%/30 } \\
\%\end{array}$ & $\begin{array}{c}\text { The main } \\
\text { task of } \\
\text { students is to } \\
\text { locate and } \\
\text { correct their } \\
\text { own errors } \\
\text { 37\%/46\%/7 } \\
\mathbf{0 \%}\end{array}$ & - & - \\
\hline
\end{tabular}

The perceived impact of feedback in subsequent essays is dramatically different depending on students' proficiency: A2 and B1 students showed balanced results, whereas $90 \%$ of B2 students claimed that their corrected mistakes would not be made again in the future. This result may be linked with responses from items 4 and 5 , in which B2 students showed a preference for having their errors self-corrected and the teacher's task was to underline and provide comments. Therefore, these techniques for error correction may help learners become aware of their wrong written output and internalize the right version. These findings are also in line with the responses for the last item, in which B2 students reported that the main task of a student was to locate and correct their own errors $(70 \%)$. Lower-level students favoured the view that it was the teacher who should carry out the correcting task. Our findings support Chen et al.'s (2016) results in that their advanced level learners required less explicit teacher's feedback and lower levels preferred the teacher to locate and indicate the type of error.

A Chi-square test (see Table 5) was applied to the above responses, and according to the English level of the participants, this test showed significant differences in the students' preferences in correction for either obtaining the right answer straightaway or having the errors located but to correct the errors themselves (item 4). A2 students significantly preferred their teacher to give them the correct answer. Therefore, the higher the English level of the students, the greater their preference for correcting the errors on their own. The second statistically significant difference refers to item 9, since A2 students claimed that errors which did not affect the understanding of the message should not be corrected. 
Table 5. Significant differences between groups depending on level of proficiency $(\mathbf{p}<0.05)$

\begin{tabular}{|l|c|c|c|}
\hline & Value $\chi^{2}$ & d.f. & Significance \\
\hline $\begin{array}{l}\text { 4. I prefer the teacher... (tells me the right } \\
\text { answer/ marks the errors and I correct } \\
\text { them) }\end{array}$ & 5.396 & 2 & .048 \\
\hline $\begin{array}{l}\text { 9. If an error does not affect the } \\
\text { understanding of the message, should it be } \\
\text { corrected? }\end{array}$ & 5.691 & 2 & .047 \\
\hline
\end{tabular}

\section{Conclusion and pedagogical implications}

Broadly speaking, the analysis of our data demonstrates that age and level of proficiency are not significant variables in the attitudes and preference towards feedback in the EFL students of the present study, as only one statistically significant difference was found for the first variable (i.e., age): older students seem to be more concerned for grammar and content than for organization or vocabulary.

The second variable under revision (i.e., proficiency level) reveals that lowlevel students prefer to be given the right answer directly. This preference may be due to the fact that, in this way, they can check the difference between the L2 and their L1. Earlier research on writing (for example, Manchón et al., 2000) has claimed that writers with a low level of proficiency in their L2 will often rely on their first-language resources, which may result in transfer errors. A second finding from the present study reveals that B2 students wish to self-correct their mistakes, corroborating recent research (Chen et al., 2016). Moreover, A2 learners do not believe that errors which do not hinder comprehension should be corrected.

In light of the results of the study, some pedagogical implications can be drawn in order to improve the provision of feedback in the L2 classroom. It may be suggested that teachers include short discussions on error correction in everyday lessons so that students clearly understand the aim of feedback and the different types and methodologies available for such practice. As suggested by Lyster et al. (2013), it is a current matter of concern to ascertain how teachers can best tailor their CF to match students' age and preferences.

Teachers should consider additional editing strategies for correcting errors in the L2 classroom. One way is to encourage students to correct their own errors. In order to do so, it would be advisable to devote some time in class to learn new editing strategies. Students would thus be able to learn how to selfcorrect under the teacher's supervision, which is indispensable to guide learners in the process. As the findings for level of proficiency of the present study show, B2 students show favourable attitudes towards locating and self-correcting their errors. In Sheen's $(2011,48)$ words, “pushing learners to stretch their 
interlanguage engages them in noticing the gap and in hypothesis testing." Not only does self-correction reinforce students' motivation and empathy towards the teaching and learning process, it can also be highly productive if students are taught how to do it. Although it may be argued that elementary learners may need guidance and explicit or direct correction, self-correction may be a useful strategy for intermediate and advanced learners. We agree with Sheen and Ellis' (2011) claims which suggest that teachers should take learners' learning goals and attitudes towards correction into account. Additionally, teachers should bear in mind the variety of correction strategies available and adjust them to the needs of individual learners. ${ }^{3}$

In summary, Sheen $(2011,174)$ concludes that "the success of feedback depends on a myriad of cognitive, sociocultural, discoursal and internal and external learner factors that mediate the effectiveness of any particular feedback type." Accordingly, if teachers take learners' factors into account- including their attitudes and preferences- correction may be more favourable; therefore, ignoring these variables while providing feedback might turn into a futile effort.

This study presents some limitations due to its exploratory nature. Firstly, the analysis of 53 EFL students' preferences about error correction and feedback cannot be generalised and may not apply to other EFL learners from different learning backgrounds. Secondly, the participants' answers are self-measured and consist of preferences, so they cannot be rated as positive or negative. Moreover, the capacity and eagerness of the participants to answer accurately and faithfully to the questions in the questionnaire may not be taken for granted. Also, the difference in age of participants was not too wide to generalize findings, although some differences have been found regarding this variable and students' preferences towards written corrective feedback.

As aforementioned, the data from this study are limited and cannot be applied to a broader spectrum. Therefore, further research is required in order to examine whether age and level of proficiency are well-grounded variables affecting the attitudes and preferences of EFL students towards written error correction. There may be many other variables which affect students' preferences for written correction, such as how long the participants have been studying English or gender. Therefore, further research could be undertaken to analyse their impact on correction and feedback, which are areas of special concern in the acquisition of a foreign language.

\footnotetext{
${ }^{3}$ As suggested by one anonymous reviewer, teachers should also try to discuss in class their learners' ideas about how languages are learnt under the scope of teachers' expertise and knowledge about this issue.
} 


\section{WORKS CITED}

Alavi, Seyyed and Shiva Kaivanpanah. "Feedback expectancy and EFL learners' achievement in English." Journal of Theory and Practice in Education 3.2 (2007): 181-96.

Ammar, Ahlem and Nina Spada. "One size fits all? Recasts, prompts and L2 learning". Studies in Second Language Acquisition 28/4 (2006): 543574. https://doi.org/10.1017/S0272263106060268

Amrhein, Hannah R. and Hossein Nassaji. "Written Corrective Feedback: What do students and teachers prefer and why?" Canadian Journal of Applied Linguistics 13 (2010): 95-127.

Chandler, Jean. "The efficacy of various kinds of error feedback for improvement in the accuracy and fluency of L2 student writing." Journal of Second Language Writing 12 (2003): 267-96. https://doi.org/10.1016/S1060-3743(03)00038-9

Chen, Sibo, Hossein Nassaji and Qian Liu. "EFL learners' perceptions and preferences of written corrective feedback: a case study of university students from Mainland China." Asian Pacific Journal of Second and Foreign Language Education 1.5 (2016). Web. 20 April 2016. $<$ https://sfleducation.springeropen.com/articles/10.1186/s40862-0160010-y>

Cohen, Andrew D. and Marilda Cavalcanti. "Feedback on written compositions: Teacher and student verbal reports." Second Language Writing: Research Insights for the Classroom. Ed. Barbara Kroll. Cambridge: Cambridge University Press, 1990. 155-77.

Corder, Stephen P. Introducing Applied Linguistics. Middlesex: Penguin, 1973.

Dulay, Heidi and Marina Burt. "Natural sequences in child second language acquisition." Language Learning 24.1 (1974): 37-53. https://doi.org/10.1111/j.1467-1770.1974.tb00234.x

Fathman, Ann and Elisabeth Whalley. "Teacher response to student writing: Focus on form versus content." Second Language Writing: Research Insights for the Classroom. Ed. Barbara Kroll. Cambridge: Cambridge University Press, 1990. 178-90.

Ferris, Dana. "Student reactions to teacher response in multiple-draft composition classrooms." TESOL Quarterly 29.1 (1995a): 33-53. https://doi.org/10.2307/3587804

---. "Teaching ESL composition students to become independent self-editors." TESOL Journal 4.4 (1995b): 18-22.

---. Treatment of error in second language student writing. Ann Arbor, MI: University of Michigan Press, 2002.

---. Response to Student Writing: Implications for Second Language Students. Mahwah, NJ: Lawrence Erlbaum, 2003.

Ferris, Dana and Marie Helt. "Was Truscott right? New evidence on the effects of error correction in L2 writing classes." Paper presented at the 
American Association of Applied Linguistics Conference. Vancouver, March 2000.

Ferris, Dana and Barrie Roberts. "Error feedback in L2 writing classes: How explicit does it need to be?" Journal of Second Language Writing 10.3 (2001): 161-84. https://doi.org/10.1016/S1060-3743(01)00039-X

Hamouda, Arafat. "A study of students and teachers' preferences and attitudes towards correction of classroom written errors in Saudi EFL context." English Language Teaching 4.3 (2011): 128-41. https://doi.org/10.5539/elt.v4n3p128

Havranek, Gertraud and Hermann Cesnik. "Factors affecting the success of corrective feedback." EUROSLA Yearbook Volume 1. Eds. Susan Foster-Cohen and Anna Nizegorodzew. Amsterdam: John Benjamins, 2001. 99-122.

Hedgcock, John and Natalie Lefkowitz. "Feedback on feedback: Assessing learner receptivity to teacher response in L2 composing." Journal of Second Language Writing 3.2 (1994): 141-63. https://doi.org/10.1016/1060-3743(94)90012-4

---. "Some input on input: Two analyses of student response to expert feedback on L2 writing." The Modern Language Journal 80.3 (1996): 287-308. https://doi.org/10.1111/j.1540-4781.1996.tb01612.x

Hendrickson, James. "Error correction in foreign language teaching: Recent theory, research, and practice." The Modern Language Journal 62.8 (1978): 387-98. https://doi.org/10.2307/326176.

Hyland, Fiona. "The impact of teacher written feedback on individual writers." Journal of Second Language Writing 7.3 (1998): 255-86. https://doi.org/10.1016/S1060-3743(98)90017-0

Hyland, Ken and Fiona Hyland. "Contexts and issues in feedback on L2 writing: An introduction." Feedback in Second Language Writing: Contexts and Issues. Eds. Ken Hyland and Fiona Hyland. Cambridge: CUP, 2006. 119. https://doi.org/10.1017/CBO9781139524742.003

Lee, Icy "How do Hong Kong English teachers correct errors in writing?" Educational Journal 31.1 (2003): 153-69.

Leki, Iliona. "The preferences of ESL students for error correction in collegelevel writing classes." Foreign Language Annals 24.3 (1991): 203-18. https://doi.org/10.1111/j.1944-9720.1991.tb00464.X

Lim, L. K. Students' Attitudes toward Errors and Error Correction in Language Learning. An Academic Exercise submitted for the award of the degree of B.A., National U of Singapore, 1990.

Lyster, Roy, Saito Kazuya. and Sato Masatoshi. "Oral corrective feedback in second language classrooms." Language Teaching, 46 (2013): 1-40. https://doi.org/10.1017/S0261444812000365

Manchón, Rosa María, Julio Roca de Larios and Liz Murphy. "An approximation to the study of backtracking in L2 writing." Learning 
and Instruction 10 (2000): 13-35. https://doi.org/10.1016/S09594752(99)00016-X

Oladejo, James. "Error correction in ESL: Learners' preferences." TESL Canada Journal 10.2 (1993): 71-89. https://doi.org/10.18806/tesl.v10i2.619

Oxford University Press, University of Cambridge, and Association of Language Testers in Europe. Quick Placement Test Paper and Pen Test. Oxford: Oxford University Press, 2001.

Schachter, Jacquelyn. "Corrective feedback in historical perspective." Second Language Research 7.2 (1991): 89-102. https://doi.org/10.1177/026765839100700202

Schulz, Renate. "Focus on form in the foreign language classroom: Students' and teachers' views on error correction and the role of grammar." Foreign Language Annals 29.3 (1996): 343-64. https://doi.org/10.1111/j.19449720.1996.tb01247.x

---. "Cultural differences in student and teacher perceptions concerning the role of grammar instruction." The Modern Language Journal 85.2 (2001): 244-58. https://doi.org/10.1111/0026-7902.00107

Sheen, Younghee. Corrective Feedback, Individual Differences and Second Language Learning. New York: Springer, 2011. https://doi.org/10.1007/978-94-007-0548-7

Sheen, Younghee and Rod Ellis. "Corrective feedback in language teaching." Handbook of Research in Second Language Teaching and Learning. Ed. Eli Hinkel. New York: Routledge, 2011. 593-610.

Storch, Neomy and Gillian Wigglesworth. "Learners' processing, uptake and retention of corrective feedback." Studies in Second Language Acquisition 32.2 (2010): 303-34. https://doi.org/10.1017/S0272263109990532

Touchie, Hanna. "Second Language Learning Errors: their Types, Causes, and Treatment." JALT Journal 8.1 (1986): 75-80.

Truscott, John. "The case against grammar correction in L2 writing classes." Language Learning 46/2 (1996): 327-69. https://doi.org/10.1111/j.14671770.1996.tb01238.x

Zacharias, Nugrahenny. "Teacher and student attitudes toward teacher feedback." RELC Journal 38.1 (2007): 38-52. https://doi.org/10.1177/0033688206076157

Zarei, Nahid. The relationship between age and corrective feedback in oral communication. Online Journal of ICT for Language Learning. 5th ed. 2011.

Zhu, Honglin. "An analysis of college students' attitudes towards error correction in EFL context." English Language Teaching 3.4 (2010): 127-30. https://doi.org/10.5539/elt.v3n4p127 
ANNEX: Questionnaire 1 (adapted from Hamouda, 2011)

NAME:

AGE:

1. I prefer my teacher to correct my essays in...

Red pen__ Green pen__ Pencil_

2. Who do you prefer to correct your essays?

The teacher__ My classmates__ Self-correction_

3. In my essays, I prefer the teacher to highlight...

All the errors__ Some errors

4. I prefer the teacher...

Tells me the right answer__ Marks the errors and I correct them

5. What do you prefer the teacher does to correct your essays?

Cross out the errors and give the appropriate words

Underline the errors and write comments at the end of the essay__

Use a correction code

Write questions

6. What kind of comments would you like your teacher to make when giving an essay back?

General comments

Specific and detailed comments

Positive comments

Negative comments

7. The most important in an essay is... 
Grammar__ Content__ Organization__ Vocabulary__

8. In your essays, the teacher should point out...

Grammar errors

Vocabulary errors

Spelling errors

Vocabulary errors

Errors on organization of ideas

9. If an error does not affect the understanding of the message, should it be corrected?

Yes__ No_

10. If there were many errors in your essay, what would you like your teacher to do?

Correct all errors

Correct only serious errors

Correct errors affecting understanding

Correct all repeated errors

11. Once your errors are corrected, do you think you will repeat them?

Yes__ No_

\section{Which statement do you agree on?}

The main task of the teacher is to locate and correct students' errors

The main task of students is to locate and correct their errors

Received: 30 May 2016

Accepted: 16 August 2016 